ノート

\title{
LC-MS/MS による農産物中のヒドラメチルノンの分析
}

(平成 22 年 5 月 28 日受理)

\author{
高橋邦彦 $1, * \quad$ 松 本 隆二 ${ }^{1}$ 根本 $\quad 3^{2} \quad$ 松田りえ子 ${ }^{2}$ \\ Analytical Method of Hydramethylnon in Agricultural \\ Products by LC-MS/MS
}
Kunihiko Takahashi, ${ }^{1, *}$, Ryuji Matsumoto ${ }^{1}$, Satoru Nemoto $^{2}$ and Rieko Matsuda ${ }^{2}$
${ }^{1}$ Saitama Institute of Public Health: 639-1 Kamiokubo, Sakura-ku, Saitama-shi, Saitama 338-0824, Japan;
${ }^{2}$ National Institute of Health Sciences: 1-18-1 Kamiyoga, Setagaya-ku, Tokyo
158-8501, Japan; * Corresponding author

\begin{abstract}
A simple determination method of hydramethylnon in agricultural products by liquid chromatography-tandem mass spectrometry (LC-MS/MS) was developed. The sample was homogenized with phosphoric acid and extracted with acetone. An aliquot of crude extract was reextracted with hexane and sat. $\mathrm{NaCl}$ solution. In the case of tea leaf, solidification processing using ammonium chloride and phosphoric acid was performed before re-extraction with hexane. Clean-up was performed using a silica-gel mini column (500 mg). The LC separation was performed on a C18 column using methanol-water $(8: 2)$ containing $10 \mathrm{mM}$ ammonium acetate as the mobile phase and MS detection with positive ion electrospray ionization. The calibration curve was linear between $0.002-0.2 \mu \mathrm{g} / \mathrm{mL}$ of hydramethylnon. Recoveries $(n=5)$ of hydromethylnon from 10 kinds of agricultural products fortified at $0.01 \mu \mathrm{g} / \mathrm{g}(0.05 \mu \mathrm{g} / \mathrm{g}$ for pineapple) were $82-110 \%$, and their relative standard deviations were $2-12 \%$.
\end{abstract}

(Received May 28, 2010)

Key words: ヒドラメチルノン hydramethylnon; 農産物 agricultural product; 液体クロマトグラ フィータンデム型質量分析法 LC-MS/MS

\section{はじめに}

ヒドラメチルノン (Fig. 1) は，アミジノヒドラジン骨格 を有する殺虫剤で，アリ，ゴキブリおよびシロアリなどに 殺虫作用を有する。日本では農薬としての登録はされてい ないが，毒餌タイプのアリやゴキブリ駆除用殺虫剂として 販売されている.

わが国の食品衛生法によるヒドラメチルノンの残留基準 は, パイナップルに暫定基準值として $0.05 \mathrm{ppm}$ が設定さ れているだけである。このため, パイナップル以外の食品 には一律基準值 $(0.01 \mathrm{ppm})$ が適用されることから, 定量 限界 $0.01 \mathrm{ppm}$ 以下を満足する分析法が必要である.

今までにヒドラメチルノンの分析法に関する報告は非常 に少ない. Stout ら ${ }^{1), 2)}$ は ECD-GC, GC-MS, UV-LCや LC-MS による農産物や牧草を分析対象とした分析法を報 告しているが, UV 検出器や ECD 検出器では感度が低い

\footnotetext{
* 連絡先 takahashi.kunihiko@pref.saitama.lg.jp

1 埼玉県衛生研究所： $\mathbf{7} 338-0824$ さいたま市桜区上大久保 639-1

2 国立医薬品食品衛生研究所： $\mathbf{T} 158-8501$ 東京都世田谷区 上用賀 $1-18-1$
}

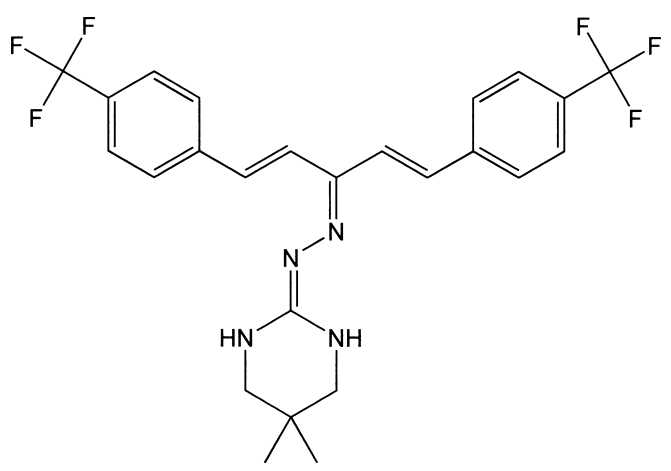

Fig. 1. Structure of hydramethylnon

こと, ジクロロメタンや塩酸を用いる抽出法, GC 測定で のパックドカラムの使用など現代的ではなく，新たな分析 法が必要であると考えられる。また, Reyzer ら゙は Solidphase microextraction (SPME)-LC-MSによる水中の七 ドラメチルノンの測定法を報告しているが，農産物を分析 対象としているものではない.

そこで, 高感度で選択性の高い LC-MS/MS を用いた農産 物中のヒドラメチルノンの分析法を検討したので報告する. 


\section{実 験 方法}

\section{1. 試料および試薬}

試料は埼玉県内で市販されている玄米，大豆，ホウレン ソウ，バレイショ，キャベッ，リンゴ，オレンジ，夕マネ ギ，パイナップルおよび茶を用いた。

ヒドラメチルノン標準品は林純薬工業(株)製の残留農薬 分析用標準品（純度 99.9\%）を用いた。標準品 $50 \mathrm{mg}$ を 精秤し, アセトンで $50 \mathrm{~mL}$ としたものを標準原液 (1 mg/ $\mathrm{mL})$ とした。ささらに，標準原液をアセトンで $1 \mu \mathrm{g} / \mathrm{mL}$ に 希釈し標準溶液とした。標準溶液を適宜メタノールー水 $(4: 1)$ 混液で希釈し検量線用標準液とした.

凝固液は塩化アンモニウム $2 \mathrm{~g}$ およびリン酸 $4 \mathrm{~g}$ に水を 加えて $400 \mathrm{~mL}$ とした。

シリカゲルミニカラムは Sep-Pak Vac Si $(500$ mg)

（Waters 社製）を使用し，あらかじめアセトンーヘキサン $(1: 4)$ 混液 $5 \mathrm{~mL}$ でコンディショニングした.

ヘキサン，アセトンおよび無水硫酸ナトリウムは残留農 薬分析用, メ夕ノールは液体クロマトグラフィー用, その 他の試薬は特級を使用した。

\section{2. 装置}

液体クロマトグラフは Waters 社製 Alliance 2695, 質 量分析装置は Waters 社製 Quattro Premier を使用した。

\section{3. 測 定条件}

LC-MS/MS の測定条件は，Table 1 に示した。

Table 1. LC-MS/MS operating conditions and MRM parameters

\begin{tabular}{ll}
\hline \hline \multicolumn{1}{c}{ Parameter } & \multicolumn{1}{c}{ Setting } \\
\hline LC conditions & YMC-pack Pro C18 \\
& $(2.0 \mathrm{~mm} \times 150 \mathrm{~mm}, 3 \mu \mathrm{m})$ \\
Column & $\mathrm{A}=$ water \\
Mobile phase & $\mathrm{B}=$ methanol \\
& $\mathrm{C}=200 \mathrm{mM}$ ammonium acetate \\
Isocratic elution & $\mathrm{A}: \mathrm{B}: \mathrm{C}=15: 80: 5$ \\
Flow rate & $0.2 \mathrm{~mL} / \mathrm{min}$ \\
Injection volume & $5 \mu \mathrm{L}$ \\
Column temperature & $40^{\circ} \mathrm{C}$ \\
MS conditions & \\
Ionization mode & Electronspray ionizotion \\
& $(\mathrm{positive} \mathrm{mode})$ \\
Capillary voltage & $3.5 \mathrm{kV}$ \\
Source temperature & $120^{\circ} \mathrm{C}$ \\
Desolvation temperature & $400^{\circ} \mathrm{C}$ \\
Cone gas flow & $\mathrm{N}_{2}, 50 \mathrm{~L} / \mathrm{hr}$ \\
Desolvation gas flow & $\mathrm{N}_{2}, 900 \mathrm{~L} / \mathrm{hr}$ \\
Collision gas & Ar \\
Transition &
\end{tabular}

\section{4. 試験溶液の調製}

\section{1 抽出}

野菜および果実は試料重量の半量の $3 \%$ リン酸水溶液を 加えてホモジナイズし，試料換算で $20 \mathrm{~g}$ に相当する量を

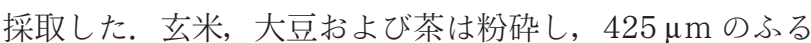
いを通過したものを使用し，玄米および大豆は $10 \mathrm{~g}$, 茶は $5 \mathrm{~g}$ を採り $3 \%$ リン酸水溶液 $20 \mathrm{~mL}$ を加えて 30 分放置し 湿潤させた。これにアセトン $100 \mathrm{~mL}$ を加えてホモジナ イズした後，ケイソウ土を敷いたろ紙を用いて吸引ろ過し た。ろ紙上の残留物はアセトン $50 \mathrm{~mL}$ で洗浄し，ろ液を 合わせアセトンで正確に $200 \mathrm{~mL}$ としたものを抽出溶液 とした.

茶以外の場合は抽出溶液 $20 \mathrm{~mL}$ を採り，飽和塩化ナト リウム溶液 $10 \mathrm{~mL}$ およびへキサン $10 \mathrm{~mL}$ を加え 5 分間 振とう後, 上層を採り $40^{\circ} \mathrm{C}$ 以下で減圧濃縮した。水が 残った場合には，エタノール $2 \mathrm{~mL}$ を加えて減圧濃縮し水 分を除去した。この残留物にアセトンーヘキサン $(1: 4)$ 混 液 $2 \mathrm{~mL}$ を加えて溶解した。

茶の場合は凝固液による操作を追加した。すなわち，抽 出溶液 $20 \mathrm{~mL}$ を採り, 凝固液 $20 \mathrm{~mL}$ およびケイソウ土 $1 \mathrm{~g}$ を加えて混和し 5 分間放置後, 3,500 rpm $(2,330 \times g)$ で 5 分間遠心分離した。上澄液を採り，残留物は凝固液一 アセトン $(1: 1)$ 混液 $20 \mathrm{~mL}$ を加えて同様に操作した。液 層を合わせ塩化ナトリウム $10 \mathrm{~g}$ およびへキサン $60 \mathrm{~mL}$ を加えて振とう後，上層を採り減圧濃縮した。水が残った 場合には，エ夕ノール $2 \mathrm{~mL}$ を加えて減圧濃縮し水分を除 去した。この残留物にアセトンーヘキサン $(1: 4)$ 混液 2 $\mathrm{mL}$ を加えて溶解した。

\section{2 精製}

シリカゲルミニカラムに上記で得られた液を負荷し，ア セトンーヘキサン $(1: 4)$ 混液 $5 \mathrm{~mL}$ で洗浄後，アセトンーへ キサン $(7: 3)$ 混液 $8 \mathrm{~mL}$ で溶出した。溶出液を減圧濃縮 し, 残留物をメ夕ノールー水 $(4: 1)$ 混液 $2 \mathrm{~mL}$ (茶の場合 は $1 \mathrm{~mL})$ で溶解したものを試験溶液とした。

\section{5. 定量}

試験溶液および標準溶液それぞれ $5 \mu \mathrm{L}$ をC-MS/MS に注入し，得られた MRM (Multiple Reaction Monitoring)クロマトグラムのピーク面積を用いて絶対検量線法 で定量した

\section{結果および考察}

\section{LC-MS/MS 測定条件の検討}

LC 条件は，分析力ラムに逆相系の C18 カラムを用い, 水一メタノール系の移動相とした。 ヒドラメチルノンは弱 塩基化合物であり，酢酸アンモニウムを添加することによ りピーク形状が向上した。数種のカラム（Mightysil RP18 GP, XTerra MS C18, XBridge C18, YMC-pack Pro C18 など）を検討した結果，いずれのカラムでも測定可 能であったが，ピーク形状が比較的良好であった YMCpack Pro C18 を使用した。 
MS の測定条件として, エレクトロスプレーイオン化 (ESI) 法を採用し，MRM モードで測定した。ヒドラメチ ルノンは，イオン化モードにポジティブモードを用いるこ とで感度良く測定できた。 プロトン化分子 $[\mathrm{M}+\mathrm{H}]^{+}$で ある $m / z 495$ をプリカーサーイオンに用い, 衝突解離に よって生じた $m / z 323$ を定量イオンに, $m / z 171$ および m/z 145 を確認イオンに用いた。 それぞれのモニターイ オンに最適な条件を Table 1 に示した.

本測定条件で，検量線は $0.002 \sim 0.2 \mu \mathrm{g} / \mathrm{mL}(5 \mu \mathrm{L}$ 注 入）の範囲で良好な直線性 $(r \geqq 0.998)$ が得られた。 ヒド ラメチルノンの 0.01 および $0.1 \mu \mathrm{g} / \mathrm{mL}$ 標準溶液を各 5 回 測定したところ, 面積值の相対標準偏差はいずれも $3 \%$ 以 内であった。

\section{2. 前処理法の検討}

\section{1 抽出法および精製法の検討}

まず，通知一斉分析法 ${ }^{*}$ を用いてヒドラメチルノンの分 析が可能であるかを検討した。 その結果, GC/MS では感 度が低く, LC/MS による農薬等の一斉分析法 I（農産物） ではグラファイトカーボン $(\mathrm{GCB})$ から溶出せず，LC/MS による農薬等の一斉分析法 II (農産物) ではシリカゲルミ 二カラムでの洗浄液で溶出し, その溶出量は一定ではな く, いずれも適用が困難であった。そこで, 個別分析法を 検討した。

抽出溶媒として, 一般的に用いられているアセトンを使 用した。残留農薬分析では, アセトン抽出液からアセトン を除去し，種々の有機溶媒で転溶抽出する方法が多用され ている。しかし，アセトン抽出液の減圧濃縮時の突沸，有 機溶媒転溶操作でエマルジョンが生成し遠心分離や長時間 の放置が必要となるなどの問題点が生じた。これらの問題 点を解消するため, 抽出液を有機溶媒に転溶する際に，ア セトンを除去せずに飽和食塩水およびへキサンを加えて抽 出する方法4)を採用した. これにより, 抽出時のエマル ジョンの発生が抑えられ, 減圧濃縮操作を省略でき, か つ, 抽出操作は 1 回で十分であった。また，ヒドラメチ ルノンは LC-MS/MS 測定で検出感度が高く, 抽出液のす べてを用いて転溶操作をする必要がないため, アセトン抽 出液の一部（1/10 量の $20 \mathrm{~mL})$ を用いることで使用溶媒 量の減少と操作時間の短縮が図れた。抽出後の減圧濃縮で 微量の水分が残存した場合は，エタノールを加えて減圧濃 縮することにより除去した。なお，ヒドラメチルノンは揮 発性が低く，減圧濃縮乾固による損失はなかった。茶にお いては転溶濃縮後に多量の残留物が存在し，ミニカラムに 全量負荷することができず回収率が低下した。 そこで，凝 固液による操作を追加したところ，残留物を除去すること ができ回収率が向上した。

精製法としてミニカラムによる精製法を検討した. $\mathrm{GCB}$ ，シリカゲル，SAX や SCX などのイオン交換カラム

*1「食品に残留する農薬, 飼料添加物又は動物用医薬品の成分 である物質の試験法について」(平成 17 年 1 月 24 日付け食 安発第 0124001 号厚生労働省医薬食品局食品安全部長通知）
を検討した結果，シリカゲルミニカラムで十分な精製効果 が得られた。 ヒドラメチルノンはアセトンーヘキサン $(1: 4)$ 混液 $5 \mathrm{~mL}$ の洗浄ではカラムに保持され, アセ卜 ンーヘキサン $(7: 3)$ 混液 $8 \mathrm{~mL}$ ですべて溶出したことから, これらの条件で洗浄および溶出操作を行った，大豆や玄米 の油脂分の多い農産物においても， シリカゲルミニカラム の洗浄段階で油脂成分が溶出し，それ以上の油分除去操作 は不要であった。 ホウレンソウ抽出液を用い，3 種のシリ カゲルミニカラム (Sep Pac Vac Si (Waters), Supelclean LC-Si (SUPELCO) および BONDELUT-SI (VARI$\mathrm{AN})$ を用いて堅牢性を検討した。各ミニカラム $(n=2)$ で の結果について分散分析を行ったところ，有意差は認めら れなかった $(p<0.05)$.

一方，ヒドラメチルノンは光分解性があることが報 告5), 6)されている。 そこで，実験室内（蛍光灯下）におけ る試料抽出液中のヒドラメチルノンの分解について検討し たが，分解は少なく実験に影響を与えることはなかった。

\section{2 標準液添加後放置による分解防止}

試料に標準溶液を添加し，30 分間放置後に抽出操作を 行ったところ，ホウレンソウ，バレイショ，オレンジで回 収率が 40〜 50\%台と低い結果となった (Table 2). 標準溶 液添加後直ちに抽出操作を行うと, 良好な回収率が得られ たことから，標準溶液添加後 30 分間放置中に何らかの原 因でヒドラメチルノンが分解し，回収率が低下したものと 考えられた。 そこで，一般的に酵素による分解の防止目的 で用いられているリン酸を添加したところ，標準溶液添加 後 30 分間放置しても，検討したすべての農産物で良好な 回收率が得られた (Table 2). 農産物の種類や個体差により 分解は一定ではないが，さまざまな農産物に対応するため に，ホモジナイズの際にはすべてリン酸を添加することと した.

\section{4. 添加回収実験}

添加回収実験用試料として，残留基準值の設定されてい るパイナップルなど 10 種の農産物を選び，パイナップル は基準值の $0.05 \mu \mathrm{g} / \mathrm{g}$, その他の試料では一律基準の 0.01 $\mu \mathrm{g} / \mathrm{g}$ となるようにヒドラメチルノンを添加した。標準溶 液を添加後 30 分間放置したのち抽出操作を行った。この 結果，5 回測定における回収率は約 82 110\%，相対標準 偏差は 2〜12\%であった (Table 2). ホウレンソウの MRM クロマトグラムを Fig. 2 に示したが，検討したすべての 試料において分析に支障となるピークは認められなかっ た。本法による定量下限 $(S / N \geqq 10)$ は $0.002 \mu \mathrm{g} / \mathrm{g}$ （大 豆，玄米および茶は $0.004 \mu \mathrm{g} / \mathrm{g}$ ）であった。

\section{謝辞}

本研究は，平成 20 年度食品に残留する農薬等の成分で ある物質の試験法開発事業（厚生労働省）により実施した あのである。関係各位に深謝いたします。 
Table 2. Recoveries of hydramethylnon from spiked agricultural products

\begin{tabular}{|c|c|c|c|c|c|}
\hline \multirow{2}{*}{ Sample } & \multirow{2}{*}{$\begin{array}{l}\text { Fortified } \\
(\mu \mathrm{g} / \mathrm{g})\end{array}$} & \multicolumn{2}{|c|}{$\begin{array}{l}\text { With addition of phosphoric } \\
\text { acid }(n=5)\end{array}$} & \multicolumn{2}{|c|}{$\begin{array}{l}\text { Without addition of phosphoric } \\
\text { acid }(n=2)\end{array}$} \\
\hline & & Recovery (\%) & R.S.D. (\%) & Recovery (\%) & R.S.D. (\%) \\
\hline Brown rice & 0.01 & 109.8 & 5.7 & 114.9 & 2.9 \\
\hline Soybean & 0.01 & 96.6 & 8.9 & 101.4 & 0.8 \\
\hline Spinach & 0.01 & 82.6 & 6.1 & 56.9 & 14.3 \\
\hline Cabbage & 0.01 & 91.9 & 2.7 & 71.6 & 4.3 \\
\hline Potato & 0.01 & 95.3 & 2.0 & 56.4 & 0.1 \\
\hline Orange & 0.01 & 92.4 & 6.7 & 42.7 & 12.9 \\
\hline Apple & 0.01 & 104.0 & 10.7 & 94.4 & 17.1 \\
\hline Pineapple & 0.05 & 93.3 & 10.7 & 102.2 & 3.8 \\
\hline Green tea leaf & 0.01 & 96.7 & 11.9 & 89.1 & 8.7 \\
\hline Onion & 0.01 & 81.7 & 9.4 & 75.4 & 2.1 \\
\hline
\end{tabular}

R.S.D.: relative standard deviation
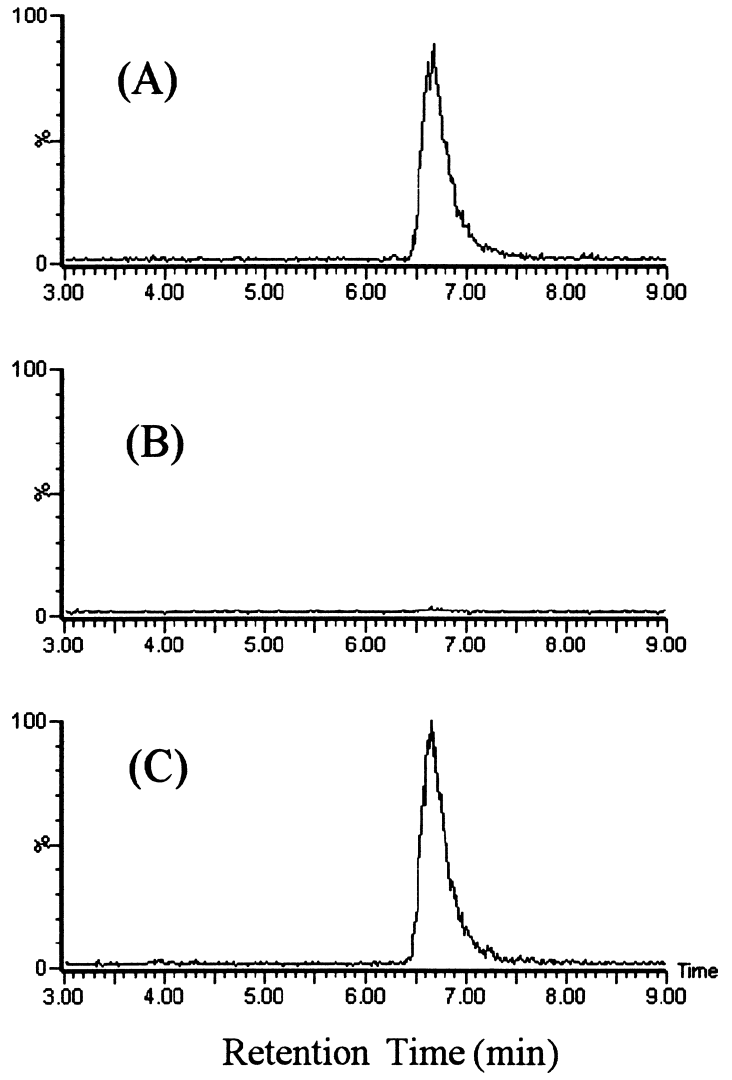

Fig. 2. MRM chromatograms $(m / z 495 \rightarrow m / z 323)$ of $(\mathrm{A})$ spinach fortified with hydramethylnon $(0.01 \mu \mathrm{g} /$ g), (B) blank spinach and (C) hydramethylnon standard $(0.01 \mu \mathrm{g} / \mathrm{mL})$
文献

1) Stout, S. J., Steller, W. A., Tondreau, R., Manuel, A. J., daCunha, A. R. Residue methodology for AMDRO fire ant insecticide (AC 217,300) in pasture grass and crops. J. Assoc. Off. Anal. Chem., 68, 71-75 (1985).

2) Stout, S. J., Peterson, R. P., Tondreau, R., daCuhna A. R., Picard, G. L. Determination of hydramethylnon residues in grass by liquid chromatography with confirmation by liquid chromatography/mass spectrometry. J. AOAC Int., 78, 862-867 (1995).

3) Reyzer, M. L., Brodbelt, J. S. Analysis of fire ant pesticides in water by solid-phase microextraction and gas chromatography/mass spectrometry or high-performance liquid chromatography/mass spectrometry. Analyt. Chim. Acta, 436, 11-20 (2001).

4) 高橋邦彦, 石井里枝, 斉藤貢一, 堀江正一. 野菜及び果実 中の残留農薬分析における抽出法の検討. 埼玉県衛生研究 所報, 33, 81-83 (1999).

5) Vander Meer, R. K., Williams, D. F., Lofgren, C. S. Degradation of the toxicant AC 217,300 in amdro imported fire ant bait under field conditions. J. Agric. Food Chem., 30, 1045-1048 (1982).

6) Mallipudi, N. M., Stout, S. J., Lee, A., Orloski, E. J. Photolysis of AMDRO fire ant insecticide active ingredient hydramethylnon (AC217,300) in Distilled Water. J. Agric. Food Chem., 34, 1050-1057 (1986). 